\title{
QUANTITATIVE AND QUALITATIVE APPROACHES OF DELINEATION IN DETAILED MAPPING OF VINEYARD LANDSCAPE. CASE STUDY: VICINITY OF PEZINOK (SLOVAKIA)
}

\author{
MARIÁN GÁBOR ${ }^{1}$, VLADIMÍR FALŤAN ${ }^{1}$, FRANTIŠEK PETROVIČ \\ ${ }^{1}$ Comenius University in Bratislava, Faculty of Natural Sciences. Department of physical geography and geoecology, \\ Mlynská dolina, Ilkovičova 6, 84215 Bratislava 4, Slovak Republic; e-mail: gabor9@uniba.sk, vladimir.faltan@uniba.sk \\ ${ }^{2}$ Constantine the Philosopher University in Nitra, Faculty of Natural Sciences, Department of Ecology and Environ- \\ ment, Trieda A. Hlinku 1, 949 74, Nitra, Slovak Republic; e-mail: fpetrovic@ukf.sk
}

\begin{abstract}
Gábor M., Faltan V., Petrovič F.: Quantitative and qualitative approaches of delineation in detailed mapping of vineyard landscape. Case study: vicinity of Pezinok (Slovakia). Ekológia (Bratislava), Vol. 35, No. 3, p. 240-252, 2016.

The main goal of this paper is the application of qualitative and quantitative free available data for geographical delineation based on reconnaissance research in vineyard landscape. The results of delineation are useful in agricultural management or environmental planning. Our delineation may serve as the basic information on site conditions of vineyards near Pezinok (Slovakia), with historical use from the beginning of $13^{\text {th }}$ century. We have studied the actual land cover and classified physiotopes of the study area into a set of relatively homogenous and coherent landscape units. The landscape units defined in this work consist of homogenous physiotopes in terms of their structural and functional characteristics, which have been shaped by natural factors (landforms, soil type and subtype, geological base, elevation, slope, aspect, solar radiation and normal different vegetation index (NDVI)). The characteristics were used to define 23 landscape units in qualitative delineation (based on both qualitative and quantitative data). Only quantitative characteristics - elevation, aspect, slope, solar radiation and NDVI, were used in a K-means cluster analysis to define the 17 landscape units. The number of landscape units was computed by WB-index, and standardisation of data was computed by factor analysis. The whole classification process was statistically significant. The strength of the grouping procedure was tested by using Discriminant Analysis, which found that $92.70 \%$ of objects in qualitative and $98.50 \%$ of objects in quantitative delineation were correctly classified.
\end{abstract}

Key words: geographical delineation, qualitative and quantitative data, agricultural management, homogenous landscape units, vineyards, Slovakia.

\section{Introduction}

Delineation, as a specialised form of classification (Chorley, Haggett, 1967), has been a basic topic in geographical, ecological and environmental sciences for a long time. The correct use of delineation methods in geographical research can allow deeper understanding 
of landscape structure on a large scale. The mosaic heterogeneity of vineyard landscape has an influence on the taste of wine and its typicity; and it is therefore important in the context of natural terroir units. Geological base, soil and topography are the most important site characteristics. The site conditions can be expressed by units of physiotopes, a geographical area having uniform topographic, lithographic and soil properties (Leopold, Völkel, 2005). Site information creates background for further research of terroir. The term terroir is widespread around the world, and it means the influences of natural factors - land properties (geological base, soil, land surface and climate), the most suitable vine variety for this site and also technical procedures of wine makers including the use of autochthonous micro organisms during fermentation (van Leeuwen et al., 2004). Information about abiotic, biotic and socio-economic components of landscape serves as assessment of landscape units (Šedivá, Izakovičová, 2015; Hreško et al., 2015). Detailed delineation of viticultural landscape is a framework for subsequent field research of natural terroir components. The aim of physical geographical delineation is grouping of a large number of physical geographical units into a small number of spatially contiguous groups based on similar properties or relationships (Chorley, Haggett, 1967). Currently, it has been applied to many diverse fields including pattern analysis (Long et al., 2010), geoecology (Olehowski et al., 2008), ecology (Hargrove, Hoffman, 2005), aquatic ecology (Jenerette et al., 2002), hydrology (Jensen et al., 2001), land consolidation (Jusková, Muchová, 2014; Ivan et al., 2014) and others.

The accuracy of input data limits the exactness of delineation. Data in geosciences can be divided into two basic categories: 1) Quantitative data defines information about quantity of the objects, which can be counted or measured and written down with numbers (e.g., elevation, slope, temperature); 2) Qualitative data describes the objects, this can't be actually measured, and it is descriptive information (e.g., soil type, soil subtype, bedrock, land cover).

Delineation can be used as a useful tool for managing environmental resources. Gallant et al. (1989) describe two basic methods of delineation involving quantitative and qualitative assessment techniques: 1) Quantitative delineation employs a statistical framework for analyzing data for the purpose of generating regions; 2) Qualitative delineation employs continual, interactive and classifying data in order to generate regions. Judgments are based on the quantity and also quality of the reference data.

Historically, geographical delineation is the most used method of qualitative delineation. It is based on the synthesis of several abiotic and/or environmental data (Leathwick et al., 2003). Qualitative approaches are based largely on expert assessment (e.g., Bezák, 1993; Wickham, Norton, 1994; Bailey, 1995; Minár et al., 2001; Blažek, Uhlíŕ, 2002; Shaohong et al., 2003; Čech, Kunáková, 2012; Perko et al., 2015). However, it currently has come to the forefront of quantitative approaches of delineation, which are based on the methodology of multivariate statistics. The main advantage of quantitative delineation is characterised by (Hargrove, Hoffman, 2005, page no. 39): 'quantitative regionalisation is more explicit, repeatable, transferable and defensible than qualitative delineation based on human expertise'. Johnston (1986 page no. 575) noted that: 'although the actual methodology employed (in classification) may be based on objective, numerical techniques: the nature of the data to be collected, the form of the analysis and the exact parameters to be used, are all subjective decisions...' The most often used quantitative delineation method is cluster analysis, until recently hierarchical meth- 
ods were used. One of the first to use a non-hierarchical method was Leathwick et al. (2003). The type of cluster analysis is affected by the size of the research area, and the type and quality of input data. Some examples of methods are: (1) hierarchical methods: TWINSPAN analysis was used by Hessburg et al. (2002), clustering with Ward's method was used by Jensen et al. (2001) or Petek (2005), two-step cluster analysis based on the BIRCH-Algorithm was used by Olehowski et al. (2008); or (2) non-hierarchical methods: k-mean clustering analysis was used by Hargrove, Hoffman (2005), the CLARA (cluster analysis for large applications) algorithm was used by Long et al. (2010). For this paper, the most inspiring method is k-mean clustering analysis. It was used by Hargrove, Hoffman (2005) for the delineation of ecoregions, Jenerette et al. (2002) used k-means analysis for delineation of aquatic systems ecoregions, $\mathrm{Xu}$ et al. (2008) used k-means analysis for delineation of region in a dry warm river valley in China, Van Eetvelde, Antrop (2009) used k-means analysis for the creation of typology in the federal state of Belgium.

The aim of this paper is to realise chosen methods of geographical delineation in a vineyard landscape on the basis of qualitative and quantitative data. The study includes methods of detailed field geo-ecological research, and the use of free available data. We have also compared results of quantitative and qualitative methods of delineation. Primary areas for delineation are types of physiotopes, homogenous units for characteristics of land use and abiotic or biotic components of the landscape (e.g., landforms, soil type and subtype, geological base, slope, elevation, solar radiation and NDVI). The result areas of delineation are landscape units representing a homogenous territory with a unique physiognomy, structure and physiography (Zonneveld, 1995). The area of the case study was localised in vineyards near the town of Pezinok. We have actually supplied information for the requirements of agricultural management.

\section{Material and methods}

\section{Study area}

The study area was $2.8 \mathrm{~km}^{2}$ (Fig. 1) and included part of the Malé Karpaty mountains in the western part of Slovakia, near the town Pezinok. It lied in a moderately warm region with July mean air temperature of $16^{\circ} \mathrm{C}$ or more. The landscape of the study area had been strongly impacted by viticultural activities, which had started at the beginning of 13th century. Land cover was formed of forest patches, grasslands, roads, pound and artificial watercourses. The soil was influenced by human impact, and had characteristics of cambic processes as found in the vineyards. The oak forest (Quercion confertae-cerris) and the Carpathian oak-hornbeam forest (Carici pilosae-Carpinenion) represented the natural vegetation.

\section{Data}

The characteristic features of elevation, solar radiation and slope were calculated using the Digital Elevation Model (DEM), which was created by interpolation of contours transposed from the base map of Slovak Republic 1:10 000 (GKÚ, 1990). Information about land cover and physiotopes was collected through detailed field researches, satellite images (Google earth) and DEM analyses. The characteristic features of soil were transposed from the map portal of Research Institute for Soil Science and Conservation of Slovak Republic in the measure 1:10 000 (VUPOP, 2012). Geological base was transposed from the Geology map of Slovakia 1:50 000 (Hraško, 2013). Information about NDVI was computed from satellite images (Landsat 8). Additional information about climate and hydrology was not available in the required scale. 


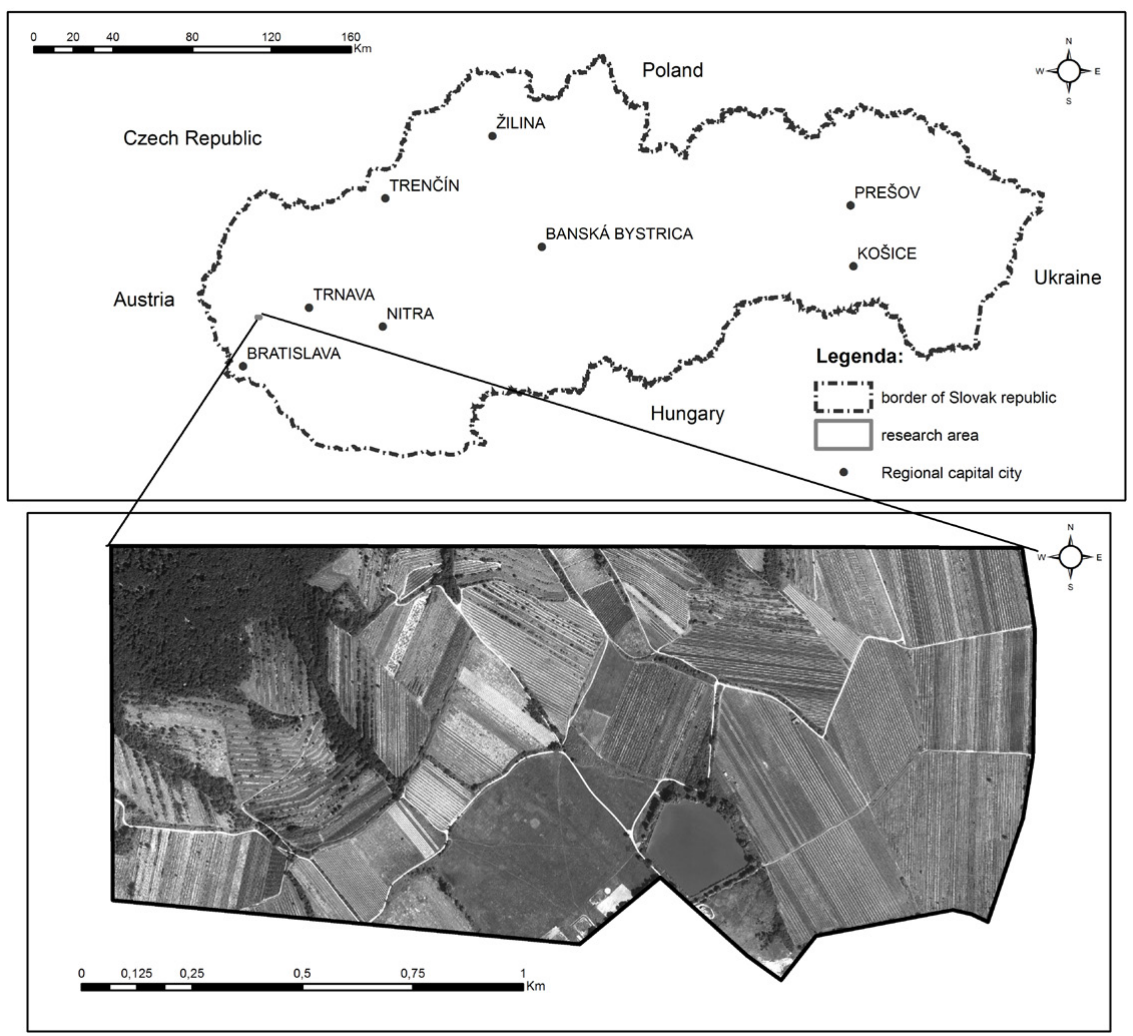

Fig. 1. Study area.

\section{Delineation of physiotopes}

The aim of physical-geographic delineation based on qualitative techniques was to identify discrete units in geographic space (McEwen, 1987). Delineation of elementary forms of the land surface (Minár, Evans, 2008) was the leading factor for delineation of physiotopes. Physical-geographic data was verified by field investigation with an integrative geoecological approach (Minár, 2003). We described local characteristics of land surface, bedrock and soils during fieldwork. Every physiotope had homogeneous landform, bedrock, soil type and subtype. A minimal area size was set at $1000 \mathrm{~m}^{2}$. Characteristic features of elevation, slope and solar radiation from DEM were calculated for each physiotope.

We also added information about actual land use for each physiotope. Land cover units were delineated by a process of adjusted methodology for a land cover mapping, realised on fourth hierarchical level (Feranec, Otahel', 1999). The unit of vineyards was separated into two subcategories: used and non-used vineyards.

Application of delineation methods

\section{Qualitative delineation}

This delineation was created on the basis of relatedness of characteristics of physiotopes. Our judgments were based on the quality and quantity of the chosen data (Gallant et al., 1989). Each characteristic had a different value accord- 
ing to its importance: value 1 had characteristics of land cover and landform, value 2 had characteristics of soil type and subtype, value 3 had characteristics of slope and solar radiation, and value 4 had characteristics of geological base and elevation. On the basis of this criterion, we grouped physiotopes into landscape units. Specific criterion was applied for physiotopes that were not useable in agricultural production (roads and water surface). Areas of vineyards had homogeneous characteristics of land cover. The most important abiotic factor (for winemakers) in vineyards of the study area was the characteristic of solar radiation, and it was the main criterion for delineation of geosystems of vineyards. The results of delineation were the maps of landscape units and a table with a detailed description of each landscape unit.

\section{Quantitative delineation}

Quantitative delineation was realised from quantitative characteristics of elevation, aspect, slope, solar radiation and NDVI. Our delineation was created by non-hierarchical k-means cluster analysis (also used by Hargrove, Hoffman, 2005; Jenerette et al., 2002; Xu et al., 2008; Van Eetvelde, Antrop, 2009; Xu et al. 2014). The type of data we had was different, and we used standardisation of data based on factor analysis. The factor analysis resulted in two factors, where the first factor explained $43 \%$ and the second factor explained $31 \%$ from total variance, and the cumulative variance for the two factors was $74 \%$. The results of factor score are given in Table. 1.

We used the iterative k-means algorithm (Harti-

T a b le 1. Factor score for each input attributes.

\begin{tabular}{|l|c|c|}
\hline \multirow{2}{*}{ Attributes } & \multicolumn{2}{|c|}{ Factor } \\
\cline { 2 - 3 } & $\mathbf{1}$ & $\mathbf{2}$ \\
\hline Slope & -0.831923 & -0.510539 \\
\hline Solar radiation & 0.896593 & 0.405095 \\
\hline Elevation & 0.444887 & -0.685865 \\
\hline Aspect & -0.316881 & 0.677353 \\
\hline NDVI & 0.605844 & -0.442623 \\
\hline Eigen values & 2.161359 & 1.549886 \\
\hline Total variance & $43.22 \%$ & $30.99 \%$ \\
\hline Cumulative variance & $43.22 \%$ & $74.22 \%$ \\
\hline
\end{tabular}
gan, 1975) which began with a user-specified number of clusters $k$, into which the physiotope have to be clustered. Each physiotope was computed progressively to find the most widely separated set of physiotopes that would provide $k$ initial centroids, one for each of the desired $\mathrm{k}$ clusters. In a single iteration, each physiotope was assigned to the closest centroid. At the end of the iteration, once all physiotopes were assigned to a centroid, an average of the coordinates of all physiotopes within each group was found to produce a new, adjusted centroid for each cluster, and then, iterations to these new centroids began. The iterative process of classifying and adjusting centroid locations continued until less than a predetermined number of physiotopes changed cluster assignments during iteration. K-means algorithm needed a user-specified number of clusters $k$, which was calculated with several formulas. We used WB-index, because it was just as accurate as other index proposed by Zhao, Fränti (2014). WB-index Zhao et al. (2009) was computed by the following formula:

$$
W B=m * S S B / S S W
$$

While $m$ was the number of clusters, SSB denoted the error sum-of-squares between different clusters and SSW the squared differences of all objects in a cluster from their respective cluster centre (Zhao, Fränti, 2014). The value for SSB and $S S W$ was computed on the basis of one-way analysis of variance ANOVA. The computing of WB-index was repeated for clusters 2 to 30, the results for which are shown in Fig. 2. The number of the cluster was found to be the best at the moment where the value of the WB-index was the smallest.

\section{Comparison of quantitative and qualitative methods of delineation}

The comparison for both types of delineation was realised on the basis of discriminant analysis. The matrix was computed by discriminant analysis, which determined the percentage of correct classification members to landscape units. Correct delineation is determined by comparison and computed by membership of landscape units. Prior probability influenced our decision about group membership, and was computed on the basis of Mahalanobis distance. Physiotopes were assigned to the landscape unit that had the smallest Mahalanobis distance from the centroid. Browne, McNicholas (2012) used multiple discriminant analysis for checking the accuracy of the landscape unit. There is a checking of quality cluster 


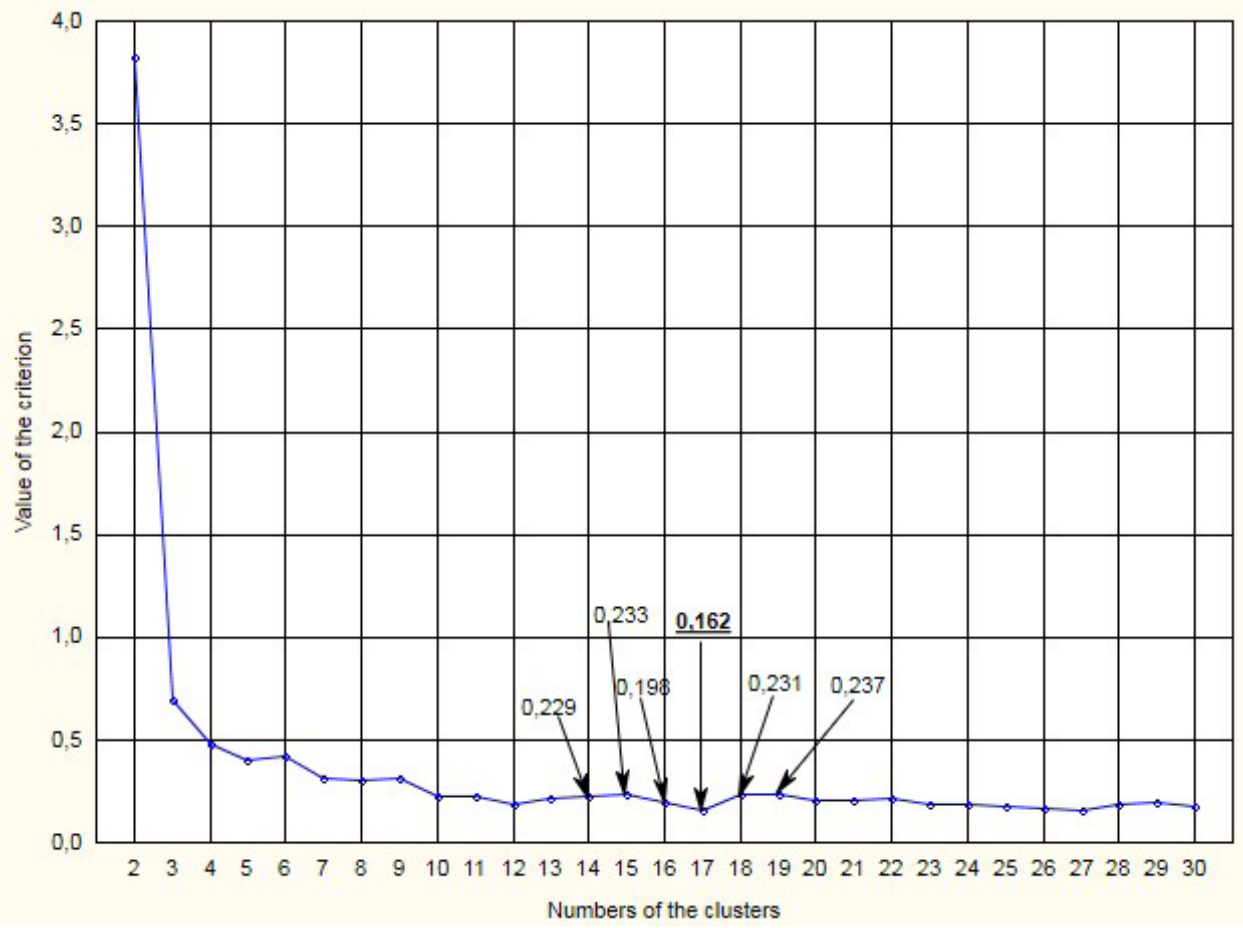

Fig. 2. Result of computing optimal number of clusters with WB-index.

analysis and a checking of power linkages of all members of landscape units, with which multiple discriminant analysis in environmental studies are used, for example Hessburg et al. (2002). Soto, Pintó (2010) used multiple discriminant analysis to test the strength of cluster analysis, and to determine which variables were significant during the clustering process. Multiple discriminant analysis builds a predictive model that shows the membership of each landscape unit.

\section{Results}

The results of qualitative delineation based on both qualitative and quantitative data were 23 landscape units of physiotopes (Fig. 3A) and a detailed description of each landscape unit (as given in Table 2). We could divide the landscape units into three categories: artificial, agricultural and forest and semi-natural landscape units. Artificial landscape units included roads, artificial watercourses and pound. We could divide the second category of agricultural landscape units into a subcategory of vineyards and permanent grasslands. Vineyards were composed with landscape units from no. 3 to no. 10. The landscape units of vineyards were divided using the information about solar radiation, geological base and elevation. The landscape units of permanent grasslands were divided primarily using the information about landforms that are on flat or sloped surfaces. In flat landforms, the landscape units were composed with nos. 11 and 12, and on slope landforms, the landscape units were composed with nos. 13 and 14 . The 


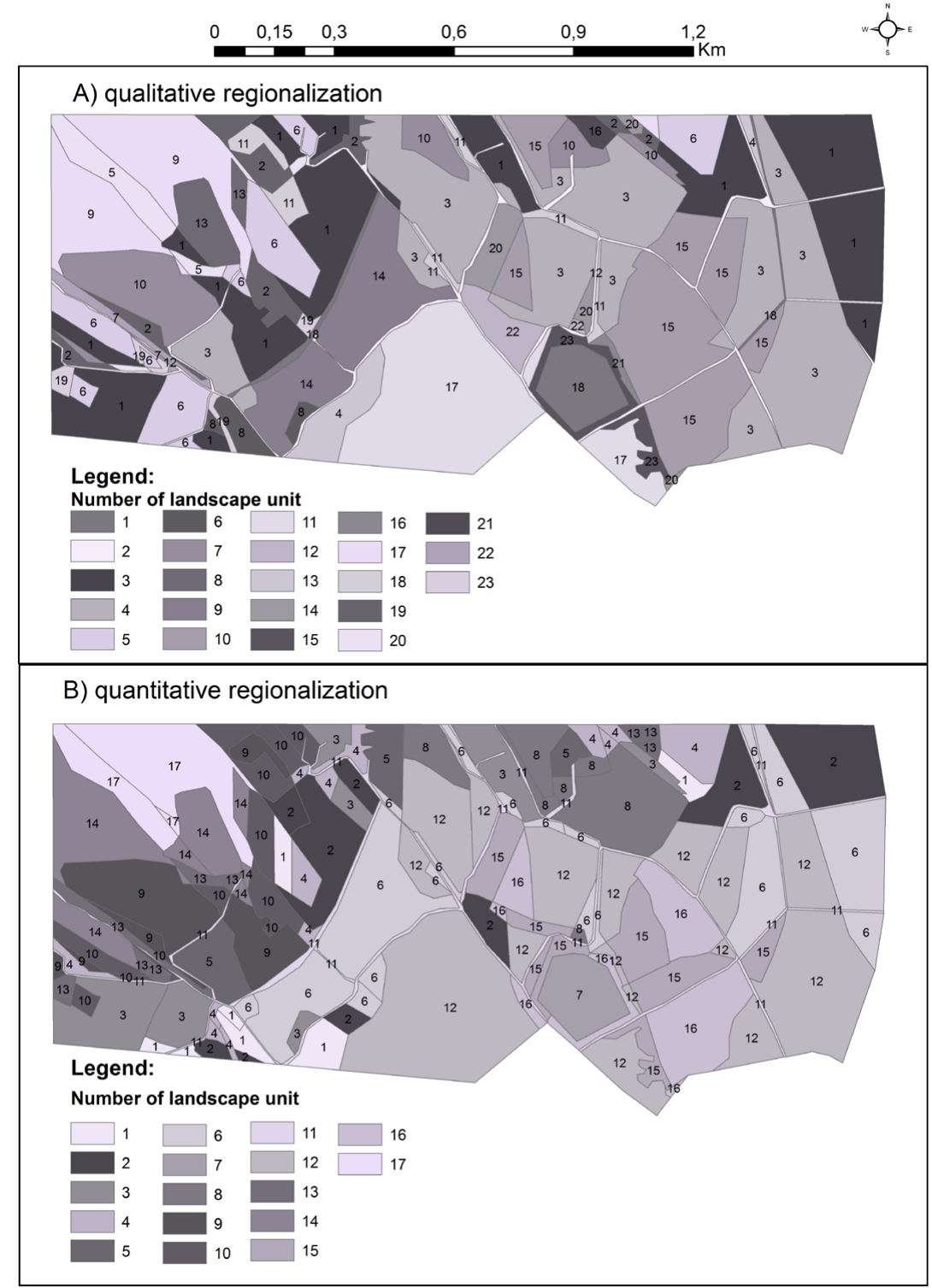

Fig. 3. Results of regionalization, A) - result of qualitative regionalization; B) result of quantitative regionalization.

last category was the natural landscape units of forest patches. This category was composed of the landscape units from no. 15 to no. 23. No. 15 was different from other landscape units regarding characteristics of landform, and it occurred on flat parts of the landscape near a pound (discontinuous forest). 
T a b l e 2. Results of qualitative delineation.

\begin{tabular}{|c|c|c|c|c|c|c|c|}
\hline $\begin{array}{l}\text { Number of } \\
\text { landscape unit }\end{array}$ & Landform & $\begin{array}{l}\text { Land } \\
\text { cover }\end{array}$ & Soil & Slope $\left(^{\circ}\right)$ & $\begin{array}{l}\text { Solar radiation } \\
(\mathrm{kW} / \mathrm{h})\end{array}$ & $\begin{array}{l}\text { Geological } \\
\text { base }\end{array}$ & $\begin{array}{l}\text { Elevation } \\
\text { (meters) }\end{array}$ \\
\hline 1 & 2 & 7,8 & 0 & 0 & 0 & 6 & 0 \\
\hline 2 & 1 & 6 & 5 & 0 & 0 & 9 & 0 \\
\hline 3 & 7 & 5 & 4 & $0-1$ & $819-862$ & $1,2,3,4$ & $178-246$ \\
\hline 4 & 7 & 4 & 4 & $0-1$ & $821-871$ & $1,5,6,7$ & $164-204$ \\
\hline 5 & 7 & 5 & 4 & $0-1$ & $797-822$ & $1,2,3,5$ & $186-216$ \\
\hline 6 & 7 & 4 & 4 & $0-1$ & $809-821$ & 5,8 & $166-185$ \\
\hline 7 & 7 & 4 & 4 & $0-1$ & $875-894$ & $1,2,3,4$ & $203-221$ \\
\hline 8 & 7 & 4 & 4 & $0-1$ & $779-801$ & 1,8 & 216 v 236 \\
\hline 9 & 7 & 4 & 4 & $0-1$ & $826-833$ & 5,6 & $170-171$ \\
\hline 10 & 7 & 4 & 4 & $0-1$ & $814-837$ & 5,7 & $168-184$ \\
\hline 11 & 5 & 3 & 3 & $0.5-1$ & $810-815$ & 8 & $161-163$ \\
\hline 12 & 5 & 3 & 1 & $0.8-2.5$ & $813-826$ & 5,6 & $163-165$ \\
\hline 13 & 4 & 3 & 1 & $1.3-2.8$ & $811-824$ & 6,7 & $160-193$ \\
\hline 14 & 4 & 2,3 & 1 & $1.9-7.8$ & $812-854$ & $3,4,5,7$ & $164-232$ \\
\hline 15 & 5 & 2 & 3 & $1-1.6$ & $812-814$ & 8 & 163 \\
\hline 16 & 4 & 2 & 3 & $1.8-3.1$ & $815-819$ & 8,9 & 164 \\
\hline 17 & 4 & 1 & 1,2 & $12.5-13.8$ & $792-896$ & 1,3 & $212-269$ \\
\hline 18 & 4 & $1,2,3$ & 1 & $0-5.9$ & $826-873$ & $1,5,6$ & $167-224$ \\
\hline 19 & 3,4 & 1,2 & 1,2 & $8.7-11.2$ & $821-878$ & $1,2,3$ & $190-284$ \\
\hline 20 & 3 & 1,2 & 1 & $9.6-10.5$ & $841-849$ & 1,2 & $204-236$ \\
\hline 21 & 4 & 1 & 1 & $17.1-19.9$ & $904-906$ & 3,1 & $225-229$ \\
\hline 22 & 9 & 1,2 & 1 & $7.3-7.5$ & $811-841$ & 1,8 & $194-211$ \\
\hline 23 & 5 & 1,2 & 1 & $5.2-9.3$ & $805-821$ & $1,2,5,8$ & $175-218$ \\
\hline
\end{tabular}

Notes: Landform: 1 - anthropogenic forms, 2 - water surface, 3 - back forms, 4 - slope forms, 5 - flat forms, 6 small valley, 7 - terrace of vineyards. Land cover: 1 - deciduous forest with a continuous canopy, 2 - deciduous forest without continuous canopy, 3 - permanent grassland, 4 - used vineyards, 5 - unused vineyards, 6 - roads, 7 - artificial watercourses, 8 - pound. Soil: 0 - water surface, 1 - eutric cambisols, 2 - eutric cambisols contaminated, 3 - mollic fluvisols, 4 -haplic umbrisols, 5 - urbi-anthropic soil. Geological base: 1 - biotite, 2 - granit, 3 -amphibolit, 4 - slate, 5 - deluvial sediment, 6 - deluvial-proluvial sediment, 7 - proluvial sediment, 8 - fluvial sediment, 9 - anthropogenic sediment.

The ideal number of clusters for $k$-mean cluster analysis for quantitative delineation was determined by $W B$-index for 17 ( Fig. 2). The results of cluster analysis are shown in Fig. 3B and a detailed description is in Table 3. The main difference between the procedures was that the quantitative approach gave the same value for every item of inputted data. Landscape units created by quantitative delineation were not formed with characteristics of landforms, land cover, soil or geological base, as in qualitative delineation. We wanted divided landscape units based on the most important characteristics (slope, solar radiation and NDVI). Landscape units no. 3 and no. 5 were formed only of vineyards, no. 7 was formed of a water pond, no. 11 was formed of roads and watercourses, because they had a higher value of NDVI and no. 17 was formed of forest. Other landscape units were not defined by land use, but by the parameter of land surface and NDVI. There were two groups of landscape units: 1) group landscape units formed of vine- 
$\mathrm{T}$ a b l e 3. Results of quantitative delineation.

\begin{tabular}{|l|c|c|c|c|c|}
\hline $\begin{array}{l}\text { Number of the } \\
\text { landscape units }\end{array}$ & Slope $\left(^{\circ}\right)$ & $\begin{array}{c}\text { Solar radiation } \\
(\mathbf{k W} / \mathbf{h})\end{array}$ & Aspect $\left(^{\circ}\right)$ & $\begin{array}{c}\text { Elevation } \\
(\mathbf{m e t e r s})\end{array}$ & NDVI \\
\hline $\mathbf{1}$ & $0.5-2.6$ & $809-839$ & $91-127$ & $162-203$ & $0.47-0.62$ \\
\hline $\mathbf{2}$ & $0.5-1.5$ & $813-859$ & $116-154$ & $160-200$ & $0.48-0.70$ \\
\hline $\mathbf{3}$ & 0.5 & $817-877$ & $106-160$ & $166-216$ & $0.55-0.65$ \\
\hline $\mathbf{4}$ & $0.5-19.9$ & $809-906$ & $93-207$ & $175-235$ & $0.54-0.72$ \\
\hline $\mathbf{5}$ & 0.5 & $863-878$ & $173-199$ & $192-208$ & $0.62-0.64$ \\
\hline $\mathbf{6}$ & $0.5-6.3$ & $817-854$ & $134-179$ & $161-206$ & $0.43-0.64$ \\
\hline $\mathbf{7}$ & 0 & 0 & 0 & 0 & 0.07 \\
\hline $\mathbf{8}$ & $0.5-2.5$ & $826-887$ & $188-209$ & $165-206$ & $0.57-0.75$ \\
\hline $\mathbf{9}$ & $0.5-9.8$ & $848-894$ & $133-181$ & $192-225$ & $0.58-0.76$ \\
\hline $\mathbf{1 0}$ & $0.5-11.6$ & $811-871$ & $97-170$ & $190-226$ & $0.59-0.79$ \\
\hline $\mathbf{1 1}$ & 0 & 0 & 0 & 0 & $0.54-0.57$ \\
\hline $\mathbf{1 2}$ & $0.5-3.07$ & $810-862$ & $171-237$ & $161-186$ & $0.48-0.73$ \\
\hline $\mathbf{1 3}$ & $0.5-12.6$ & $797-848$ & $90-132$ & $197-236$ & $0.64-0.79$ \\
\hline $\mathbf{1 4}$ & $0.5-13.4$ & $779-896$ & $75-174$ & $212-269$ & $0.69-0.80$ \\
\hline $\mathbf{1 5}$ & $0-5.8$ & $811-847$ & $194-250$ & $162-180$ & $0.51-0.63$ \\
\hline $\mathbf{1 6}$ & $0.5-1.9$ & $810-834$ & $193-255$ & $162-176$ & $0.49-0.57$ \\
\hline $\mathbf{1 7}$ & $8.6-13.8$ & $800-856$ & $89-136$ & $257-284$ & $0.77-0.78$ \\
\hline
\end{tabular}

yards and areas used for new vineyards $(1,2,6,8,9,12$, and 16); and 2) group landscape units formed of non-vineyards areas and unsuitable vineyards with bad conditions that were used for corridor migration animals or as a forest or meadow patch $(4,10,13,14$, and 15).

The results were exact in both delineation types. The delineation based only on quantitative data (delineation B) was $98.50 \%$ accurate and the qualitative delineation (delineation A) was $92.70 \%$ accurate. Delineation A had the same accuracy rate for 17 of the landscape units. Delineation B had a 100\% accuracy rate for 14 of the landscape units. Both of them were highly accurate. We expected some compliance between both the delineations on the basis of comparison, but overall this gave a different result. Inadequate conformity was caused by the inputted data, because we only had limited inputs available.

Comparison accuracy of border was created by comparing the results of qualitative and quantitative landscape units with orthophoto image based on the expert opinions of authors (Fig. 4). The comparison of results on the orthophoto image showed that qualitative delineation brought better results than quantitative delineation for use in agricultural management, because qualitative delineation was better at showing land use of landscape. Qualitative delineation had better results in current agricultural management and in the European Union agricultural funding or state agricultural funding. The benefits of quantitative delineation can be used in planning new vineyards, because they separated areas on the basis of solar radiation. Solar radiation is necessary for increasing the quality of grape production, but high solar radiation can destroy metabolic processes in grape wine. At this point, we saw that quantitative delineation had a higher accuracy rate, but in specific examples agricultural management provided qualitative delineation with the same or better results. 


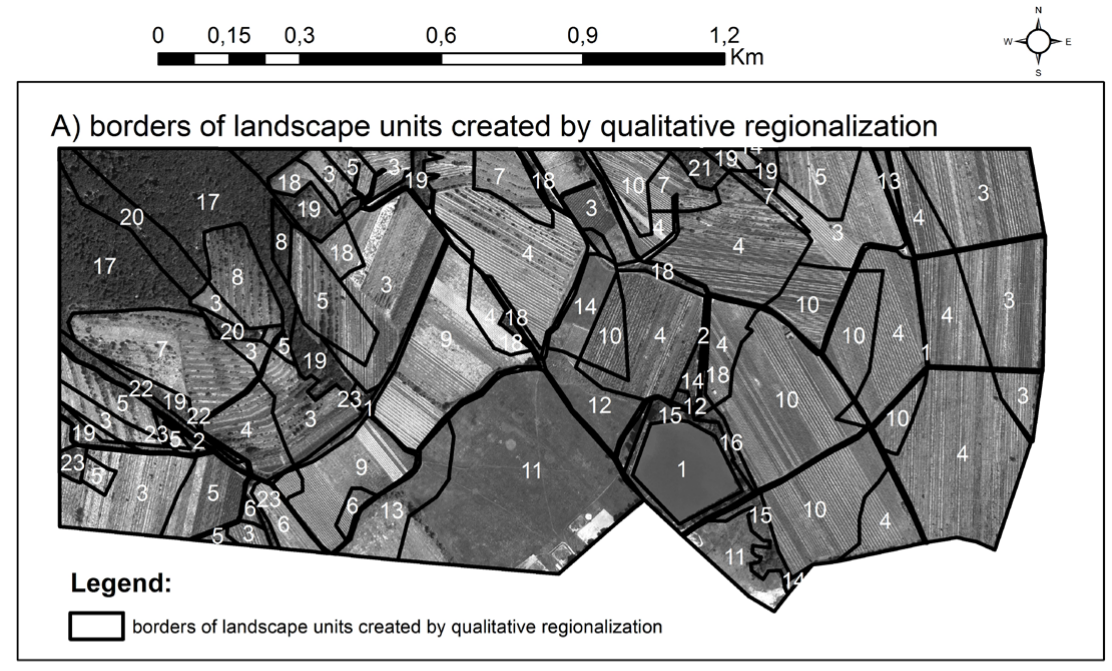

B) borders of landscape units created by quantitative regionalization

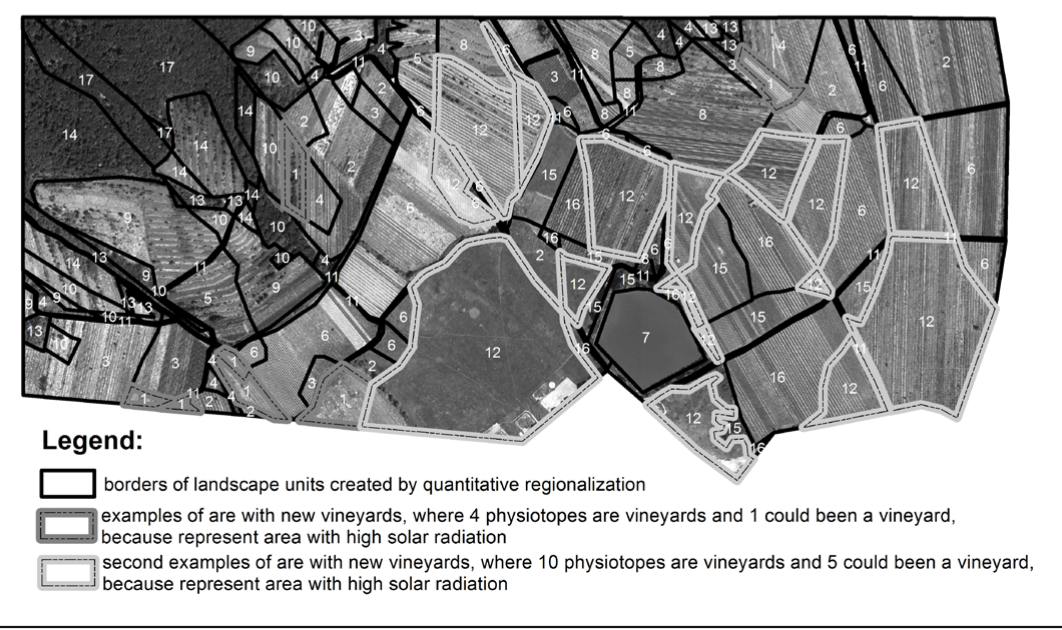

Fig. 4. Comparison of border accuracy in quantitative and qualitative regionalization on the basis of orthophoto image of research area.

\section{Discussion}

Qualitative delineation is more subjective than quantitative delineation, and this can involve a decrease in quality in this type of delineation. Confronting the expert opinion of authors is a problem, because each author can create different types of delineation. Quantitative delineation has a countless number of advantages, the most important being the advanced rate of objectivity as compared to qualitative delineation (Hargrove, Hoffman, 2005). 
Discriminant analysis has been widely used in quantitative delineation. Heino et al. (2002) reached $84 \%$ result accuracy in ecoregions and $74.4 \%$ in subregions, Bakhsh, Kanwar (2005) had $86 \%$ result accuracy, Soto and Pintó (2010) had 86\% result accuracy and Hessburg et al. (2002) had $89 \%$ result accuracy. The result of discriminant analysis in this paper is $98.50 \%$ in quantitative delineation and $92.70 \%$ in qualitative delineation. When we got results of quality that was higher than $90 \%$, we were inclined to agree with the authors Leathwick et al. (2003) or Hargrove, Hoffman (2005), that a selection of inputted data can also be realised on the basis of overview literature and maps. Nevertheless, it is very important to select the most accurate and high quality input data (Xu et al., 2014). Hargrove, Hoffman (2005) take into account that different strengths given for each criterion by authors can be one of the greatest disadvantages of qualitative delineation. Also Leathwick et al. (2003), we had in comparison of delineation methodology some degree of compliance and we expected the biggest degree of conformity with the biggest database of quantitative criterion.

We agree with Hessburg et al. (2002), that ecological regions are using representative sampling for developing, monitoring and conservation designs. Leathwick et al. (2003) used the regions for biodiversity management and we could use the results of quantitative delineation for the planning of new vineyards in areas with high solar radiation, but areas with low solar radiation between the vineyards could be used as a corridor for migratory animals between forests. Long et al. (2010) used regions for examining the spatial distribution of forest pattern. Soto, Pintó (2010) used landscape units created on the basis of quantitative delineation in planning and land management in the archipelago of Puerto Rico, and this is very similar with our delineation purpose.

\section{Conclusion}

Many components of the cultural landscape, especially at the regional scale, indicate at its fundamental functions and show the spatial organisation of the geosystems. The cultural landscape is multifunctional, and many of its features can be analysed and examined only on a local scale. Protection of traditional cultural landscapes not only contributes to the preservation of cultural values of the country, but also to maintaining and preserving biodiversity and the ecological stability of the area, and its natural and cultural character (Hrnčiarová, 2008).

We used both qualitative and quantitative data and compared the quantitative and qualitative physical geographical delineation methodologies with delimited data sources, which are available without time and financial consuming research in vineyard landscape. Outputs of qualitative delineation can be used for evaluation of environmental sustainability and agricultural management. Outputs of quantitative delineation can also be used for planning new vineyards, or for planning of environmental utilisation of landscape. We summarise the process of delineation into following steps: (1) selection of delineation criteria chosen on the basis of expert opinion or by literature review, in the case of quantitative characteristics it is possibly used in correlation analysis for selecting delineation criteria. (2) Application of selected delineation methodology. (3) Border accuracy determination of landscape units based on discriminant analysis, and in the case of the low accuracy, return to the first step and select another characteristic. (4) Delimitation of the borders of landscape units and refill each relevant characteristic into landscape units. Separate steps in the case of cluster analysis by selecting the correct 
numbers of clusters. Quantitative delineation has recently been more frequently used because it is more accurate, verifiable and repeatable than qualitative delineation. However, qualitative delineation methodology is a successful possibility used in specific research cases.

\section{Acknowledgements}

The study was supported by the Scientific Grant Agency of the Ministry of Education of Slovak Republic and Slovak Academy of Science (project no. 1/0421/16). Field work was realised through cooperation with Viticulture Pavelka and Son, Pezinok.

\section{References}

Bailey, R.G. (1995). Description of the ecoregions of the United States. Miscellaneous publication, 1391. Washington D. C.: U.S. Forest Service.

Bakhsh, A. \& Kanwar R.S. (2005). Spatial clusters of subsurface drainage water $\mathrm{NO}_{3} \mathrm{~N}$ leaching losses. Journal of the American Water Resources Association, 41, 333-341. DOI: 10.1111/j.1752-1688.2005.tb03739.x.

Bezák, A. (1993). Problems and methods of regional taxonomy (in Slovak). Geographia Slovaca, 3, 96.

Blažek, J. \& Uhliř D. (2002). Regional development theories. Outline, criticism classification (in Czech). Praha: Universita Karlova v Praze, Nakladatelství Karolinum.

Browne, R.P. \& McNicholas P.D. (2012). Model-based clustering, classification, and discriminant analysis of data with mixed type. Journal of Statistical Planning and Inference, 142, 2976-2984. DOI: 0.1016/j.jspi.2012.05.001.

Čech, V. \& Kunáková L. (2012). Geoecological research and geoecological database (case study: cadastral area of village Kolinovce) (in Slovak). Geografický Ćasopis, 64, 105-118.

Feranec, J. \& Otahel' J. (1999). Mapping of land cover at scale 1:50 000: draft of the nomenclature for the Phare countries (in Slovak). Geografický Časopis, 51, 19-44.

Gallant, A.L., Whittier, T.R., Larsen, D.P., Omernik, J.M. \& Hughes R.M. (1989). Regionalization as a tool for managing environmental resources. Corvallis: Corvallis Environmental Research Laboratory and NSI Technology Services.

GKÚ (1990). Base map of Slovakia 1:10 000 - raster form, Bratislava (in Slovak). Bratislava: Geodetický a kartografický ústav.

Hargrove, W.W. \& Hoffman F.M. (2005). Potential of multivariate quantitative methods for delineation and visualization of ecoregions. Environ. Manag., 34, 39-60. DOI: 10.1007/s00267-003-1084-0.

Hartigan, J.A. (1975). Clustering algorithms. New York: John Wiley and Sons.

Heino, J., Muotka, T., Paavola, R., Hämäläinen, H. \& Koskenniemi E. (2002). Correspondence between regional delineations and spatial patterns in macro invertebrate assembladges of boreal headwater streams. J. North Am. Benthol. Soc., 21, 397-413. http://www.jstor.org/stable/1468478

Hessburg, P.F., Salter, R.B., Richmond, M.B. \& Smith B.G. (2002). Ecological subregions of the interior Columbia Basin, USA. Appl. Veg. Sci., 3, 163-180. DOI: 10.2307/1478995.

Hraško, L. (Eds.) (2013). Geology map of Slovakia 1:50 000 (in Slovak). Bratislava: Štátny geologický ústav Dionýza Štúra. Available at: http://mapserver.geology. sk/gm50js (accessed October 2013).

Hreško, J., Petrovič, F. \& Mišovičová R. (2015). Mountain landscape archetypes of the Western Carpathians (Slovakia). Biodivers. Conserv., 24(13), 3269-3283. DOI: 10.1007/s10531-015-0969-6.

Hrnčiarová, T. (2008). Historical landscape structure - important part of landscape diversity (in Slovak). In V. Herber (Ed.), Fyzickogeografický zbornik 6. fyzická geografie a trvalá udržitelnost (pp. 39-44). Př́spevky z 25. výroční konference fyzickogeografické sekce České geografické společnosti konané 31. ledna 2008 v Brně. Brno: Masarykova univerzita.

Chorley, R.J. \& Haggett P. (1967). Models in geography. London: Methuen.

Ivan, P., Jarabicová, M. \& Muchová Z. (2015). Assessment of changes in landuse by coefficient of the ecological stability. 15th International Multidisciplinary Scientific Geoconference and EXPO. Albena: SGEM, 1(5), 73-80.

Jenerette, G.D., Lee, J. \& Norton D.J. (2002). Multivariate analysis of the ecoregion and delineation for aquatic systems. Environm. Manag., 29, 67-75. DOI: 10.1007/s00267-001-0041-z.

Jensen, M.E., Goodman, I.A., Bourgeron, P.S., Poff, N.L. \& Brewer C.K. (2001). Effectiveness of biophysical criteria in the hierarchical classification of drainage basins. Journal of the American Water Resources Association, 37, 1155-1167. DOI: $10.1111 /$ j.1752-1688.2001.tb03629.x. 
Johnston, R.J. (1968). Choice in classification: the subjectivity of objective methods. Annals of the Association of American Geographers, 58, 575-589. DOI: 10.1111/j.1467-8306.1968.tb01653.x.

Jusková, K. \& Muchová Z. (2014). Options and trends of land consolidation in the Czech and Slovak Republic, with regard to common historical development of ownership and usage rights. 14th International Multidisciplinary Scientific Geoconference and EXPO. Albena: SGEM, 2(5), 471-478.

Leathwick, R.J., Overton, M.J. \& McLeod M. (2003). An environmental domain classification of New Zealand and its use as a tool. Conserv. Biol., 17, 1612-1623. DOI: 10.1111/j.1523-1739.2003.00469.x.

Leopold, M. \& Völkel J. (2005). Methodological approach and case study for the reconstruction of a (pre)historic land use model. Zeitschrift für Geomorphologie, 139(Suppl.), 173-188.

Long, J., Nelson, T. \& Wulder M. (2010). Regionalization of landscape pattern indices using multivariate cluster analysis. Environm. Manag., 46, 134-142. DOI: 10.1007/s00267-010-9510-6.

McEwen, W.M. (Eds.) (1987). Ecological districts and regions of New Zealand. Four maps (1:500 000). New Zealand Biological Resources Centre publication 5. Department of Conservation, Wellington, New Zealand.

Minár, J., Barka, I., Bonk, R., Bizubová, M., Čerňanský, J., Faltan, V., Gašpárek, J., Kolény, M., Kožuch, M., Kusendová, D., Machová, Z., Mičian, L., Mičietová, E., Michalka, R., Novotný, J., Ružek, I., Švec, P., Tremboš, P., Trizna, M. \& Zatko M. (2001). Geoecological (complex physical-geographical) and mapping at large scales (in Slovak). Geografické Spektrum, 3. Bratislava: Geo-grafika.

Minár, J. (2003). Detailed physical-geographical (geoecological) research and mapping in the landscape ecology. Ekológia (Bratislava), 22, 141-149.

Minár, J. \& Evans I.S. (2008). Elementary forms for land surface segmentation: The theoretical basis of terrain analysis and geomorphological mapping. Geomorphology, 95, 236-259. DOI: 10.1016/j.geomorph.2007.06.003.

Olehowski, C., Naumann, S., Fischer, D. \& Siegmund A. (2008). Geo-ecological spatial pattern analysis of the island of Fogo (Cape Verde). Global and Planetary Change, 63, 188-197. DOI: 10.1016/j.gloplacha.2008.09.006.

Perko, D., Hrvatin, M. \& Ciglič R. (2015). A methodology for natural landscape typification of Slovenia. Acta Geographica Slovenica, 55, 235-270. DOI: 10.3986/AGS.1938.

Petek, F. (2005). Typology of Slovenia's region with emphasis on land use and changes in land use. Acta Geographica Slovenica, 45, 33-52. DOI: 10.3986/AGS45102.

Shaohong, W.U., Qinye, Y. \& Du Z. (2003). Delineation of eco-geographic regional system of China. Journal of Geographical Sciences, 13, 309-315. DOI: 10.1007/BF02837505.

Soto, S. \& Pintó J. (2010). Delineation of natural landscape units for Puerto Rico. Applied Geography, 30, 720-730. DOI: 10.1016/j.apgeog.2010.01.010.

Šedivá, A. \& Izakovičová Z. (2015). Assessment of representative landscape types of Skalica district. Ekológia (Bratislava), 34(4), 329-338. DOI: 10.1515/eko-2015-0030.

Van Eetvelde, V. \& Antrop M. (2009). A stepwise multi-scaled landscape typology and characterization for transregional integration, applied on the federal state of Belgium. Landsc. Urban Plann., 91, 160-170. DOI: 10.1016/j. landurbplan.2008.12.008.

Van Leeuwen, C., Friant, P., Chone, X., Tregoat, O., Koundouras, S. \& Dubordieu D. (2004). Influence of climate, soil, and cultivar in terroir. Am. J. Enol. Vitic., 55, 207-217.

VUPOP (2012). Valuated soil-ecological units 1:50 000 (in Slovak). Bratislava: VÚPaOP. Available at: http://www. podnemapy.sk/ bpej/viewer.htm?activelayer=2\&layers $=001$ (accessable November 2013).

Wickham, J.D. \& Norton D.J. (1994). Mapping and analyzing landscape patterns. Landsc. Ecol., 9, 7-23. DOI: 10.1007/ BF00135075.

Xu, Ch., Sheng, S., Chi, T., Yang, X., An, S. \& Liu M. (2014). Developing a quantitative landscape regionalization framework integrating driving factors and response attributes of landscapes. Landscape Ecology Engineering, 10, 295-307. DOI: 10.1007/s11355-013-0225-8.

Xu, X.L., Ma, K.M., Fu, B.J., Song, C.J. \& Liu W. (2008). Relationships between vegetation and soil and topography in a dry warm river valley, SW China. Catena, 75, 138-145. DOI: 10.1016/j.catena.2008.04.016.

Zhao, Q., Xu, M. \& Fränti P. (2009). Sum-of-square based cluster validity index and significance analysis. In 9th International Conference on Adaptive and Natural Computing Algorithms (pp. 313-322). ICANNGA, Kuopio, Finland. DOI: 10.1007/978-3-642-04921-7_32.

Zhao, Q. \& Fränti P. (2014). WB-index: A sum of squares based index for cluster validity. Data \& Knowledge Engineering, 92, 77-89. DOI: 10.1016/j.datak.2014.07.008.

Zonneveld, I.S. (1995). Land ecology. Amsterdam: SPB Academic Publishing. 